\title{
The Feasibility of Flipped Classroom Teaching Model in the Writing Course via ICLASS for Non-English Major Students
}

\author{
JIAO Li-xia \\ Beijing University of Posts and Telecommunications, Beijing, China
}

\begin{abstract}
The present paper probes into the feasibility of flipped classroom teaching model in writing for non-English majors. The flipped classroom teaching model changes the teaching structure in the traditional classrooms. It puts students at the center of study in the whole study process, gives more autonomy to students both in class and outside of class, and involves students in the cooperation and interaction with their peers or the teacher. The process of writing teaching in the flipped classrooms via ICLASS is designed in the present paper and hopefully it will help non-English major students to improve their overall proficiency in writing.
\end{abstract}

Keywords: flipped classroom, traditional classroom, writing, ICLASS, proficiency

\section{Introduction}

Writing is an indispensable skill for students. However, a majority of students, especially non-English majors find it hard for them to write well in English. Their writings are problematic in a variety of aspects, including content, organization, grammar, diction, the use of rhetorics, etc. Many students complain that they have made little progress in writing although they have spent much time and energy on the writing practice; many teachers have the complaint that they have made great endeavors to teach students the writing techniques and to give feedback to students' writings but their efforts do not seem to pay off.

It is known that in the traditional writing classroom, the process of teaching usually goes on as follows: Teachers introduce the writing strategies first and then they assign certain writing topics to students, who are expected to turn in the compositions they have written within a certain time. Teachers are to correct all their writings by either global scoring or analytic scoring. If time allows, teachers are expected to give some comments on their writings. Students are hopefully to improve their writings by correcting the errors based on teachers' corrections or suggestions. But the iron fact that students' writings cannot be improved in this way has provoked the researcher into finding out a way out for students to improve their writings effectively and efficiently. Flipped classroom teaching model might be a good choice.

\section{Flipped Classroom Teaching Model}

Flipped classroom, also known as inverted classroom, originated in the US. The two chemistry teachers named Jonathan Bergmann and Aaron Sams in Woodland Park High School in the US initiated the model by

JIAO Li-xia, lecturer, master, School of Humanities, Beijing University of Posts and Telecommunications. 
uploading their course slides and lectures to YouTube so that the students can accomplish their learning tasks without having to trek to school. This was the embryo of flipped classroom. But it was Salman Khan and the Khan Academy that he established that popularized the concept.

Flipped classroom is an instructional strategy and a type of blended learning that reverses the traditional learning environment by delivering instructional content in the form of documents, coordinated slides, audios and videos, etc., often online, outside of the classroom. It moves activities, including those that may have traditionally been considered homework, into the classroom. In a flipped classroom, students watch online lectures, collaborate in online discussions, or carry out research at home and engage in concepts in the classroom with the guidance of a mentor.

As can be seen, in flipped classrooms, learning involves the following stages: students independently watching relevant videos or listening to audios and reading relevant teaching materials (all the audios, videos, and documents have been meticulously made in advance by the teacher), students autonomously internalizing knowledge by doing their homework and finishing online tests, students getting involved in student-student or teacher-student interaction, working out problems they have come across before and thoroughly digesting the knowledge they have newly acquired. The differences between flipped classrooms and traditional classrooms are depicted by JIN Ling (2016) as follows:

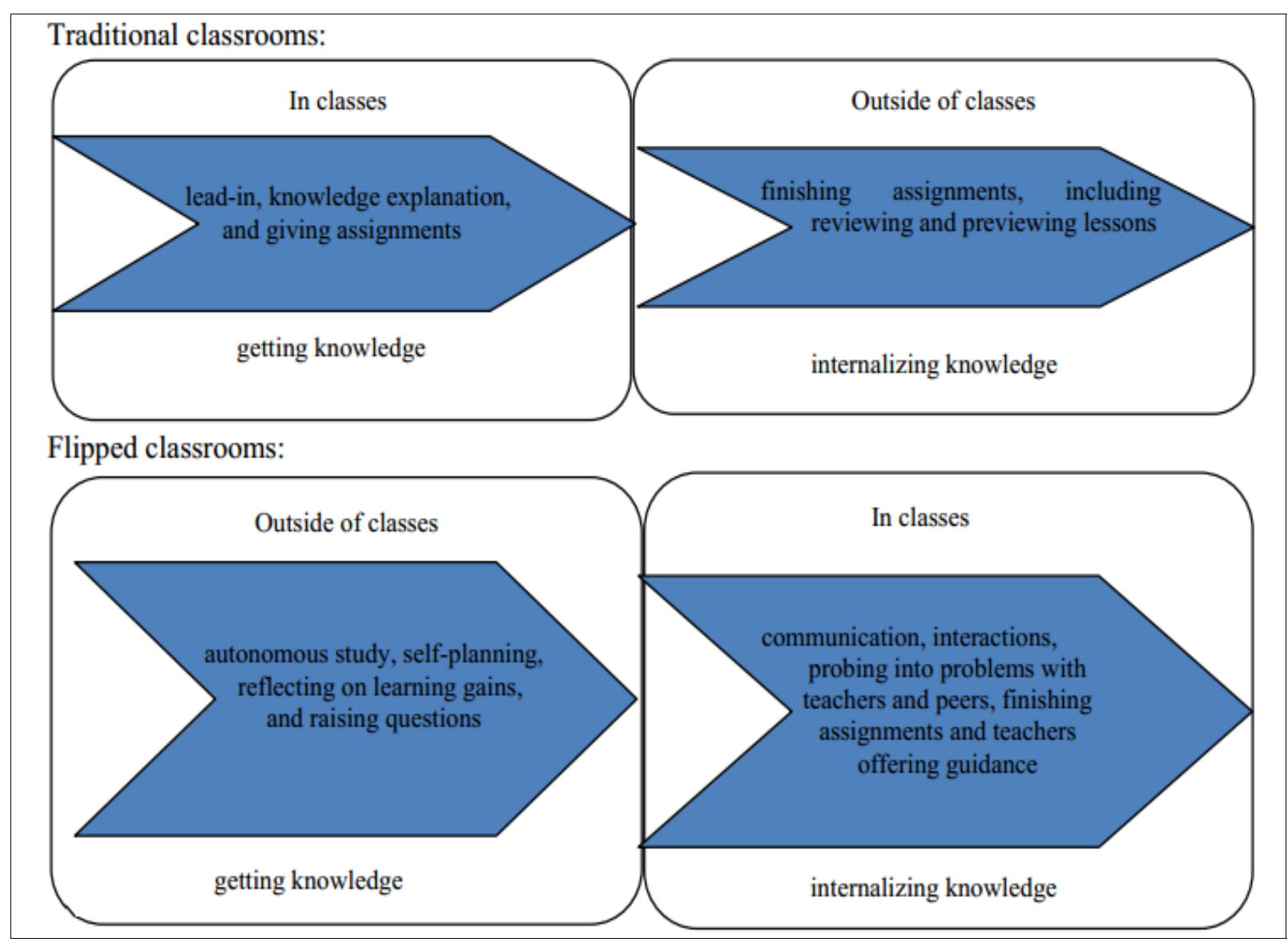

Figure 1. The difference of teaching structure between traditional and flipped classrooms (JIN, 2016, p. 15). 
As can be seen from Figure 1, the flipped classroom teaching model coincides with the theories of constructivism, in which framework learners are believed to obtain knowledge through meaning construction on the learners' part in a certain context with the help of the teacher and peers. In the whole learning process, learners themselves should play the main role. For the adult learners, such as college or university students, compared with the rigidly uniform traditional classrooms, flipped classroom teaching model may better cater to their needs of deciding their own learning pace since "adult learners vary markedly in their attitudes towards learning, their preferred learning styles and their perceptions of what is of value and what is not" (Willing, 1985 in Nunan, 2012, p. 23) and "...one of the fundamental principles underlying the notion of permanent education is that education should develop in individuals the capacity to control their destiny and that, therefore, the learner should be seen as being at the centre of the educational process" (Brindley, 1984 in Nunan, 2012, p. 23).

\section{The Feasibility of Flipped Classroom Teaching Model in Writing Classes}

The flipped classroom entails the massive use of the internet and the guarantee of technological support, which is available in the researcher's school, where a platform named "ICLASS" has been established and put to use. The platform includes such different items as homepage, teaching syllabus, course materials, learners' grouping, assignments, online testing, and course tools, each serving its/their own function. Homepage gives students the notices and tasks given by the teacher; teaching syllabus is a course description. The teaching goals, teaching content, and course books are introduced in this section. In the "course materials" section, the documents, slides, audios, and videos of each chapter are provided. Students are grouped in terms of different criteria in the "learners' grouping" section. Students are to finish and turn in their assignments in the "assignments" section. Students can finish tests in the "online testing" section. The "course tools" section is to facilitate students' interaction by including different interactive tools, such as Wiki, blogs, logs, billboards, etc. The use of ICLASS will facilitate the flipped classroom teaching model in writing.

In a flipped classroom, the process of writing teaching goes as follows:

Outside of classes: teachers producing audios and videos and uploading them to the ICLASS platform - students listening to the audios and watching the videos and in the process keeping a record of the important and difficult points - students finishing the assignments (optional).

In classes: students interacting with their classmates or their teachers about the points they have learned from the audios or videos they have previously dealt with, especially the important and difficult points they have recorded before class or students finishing the assignments in class - students peer-assessing their assignments or the teacher assessing their assignments - teachers giving feedback individually, or to a group or to the whole class.

Based on the problems the researcher has identified in students' writings, the teacher is to make audios or videos concerning the different aspects of writing and each aspect can further contain different items as is shown in the following table: 
Table 1

Topics of Audios or Videos for the Flipped Classroom Writing Teaching Model

\begin{tabular}{|c|c|c|}
\hline General topics & \multicolumn{2}{|l|}{ Further division } \\
\hline \multirow{3}{*}{ Content } & \multicolumn{2}{|c|}{ How to brew ideas through brainstorming } \\
\hline & \multicolumn{2}{|c|}{ How to develop critical thinking } \\
\hline & \multicolumn{2}{|c|}{ How to ensure the unity, integrity, and logic of passages and paragraphs } \\
\hline \multirow{2}{*}{ Organization } & \multicolumn{2}{|c|}{ How to write a composition in a proper order such as the chronological order, spatial order, logical order, etc. } \\
\hline & \multicolumn{2}{|c|}{ How to write outlines in complete sentences or in words or word groups } \\
\hline \multirow{5}{*}{ Language } & \multicolumn{2}{|c|}{ How to avoid grammatical errors on the syntactical level } \\
\hline & \multicolumn{2}{|c|}{ How to avoid grammatical errors on the lexical level } \\
\hline & \multicolumn{2}{|c|}{ How to enrich the sentence structures } \\
\hline & \multicolumn{2}{|c|}{ How to use both proper and appropriate diction } \\
\hline & \multicolumn{2}{|c|}{ How to avoid the negative transfer of mother tongue } \\
\hline \multirow{8}{*}{$\begin{array}{l}\text { Writing } \\
\text { techniques }\end{array}$} & \multirow{2}{*}{ Narration } & How to select the writing materials \\
\hline & & How to include the six elements in narration, i.e., when, where, who, what, why, and how \\
\hline & \multirow{2}{*}{ Description } & How to be a good observant \\
\hline & & How to show the distinctive features of objects or people \\
\hline & \multirow[b]{2}{*}{ Exposition } & How to distinguish different types of exposition \\
\hline & & $\begin{array}{l}\text { How to ensure that the exposition is informative, scientific, logical, and complete, if possible, } \\
\text { of some interest }\end{array}$ \\
\hline & \multirow{2}{*}{ Argumentation } & How to collect arguments, including statistics, examples, facts, personal experiences, etc. \\
\hline & & How to argue logically \\
\hline & \multirow{2}{*}{ Applied writings } & How to write letters in proper format \\
\hline & & How to abide by the " $5 \mathrm{C}$ " principles in business letters \\
\hline
\end{tabular}

As is conveyed in Table 1, 20 videos are to be made, each elaborating on one of the 20 items listed. Each 20 to 30-minute video contains slides and teachers' lecturing. The teacher is to lecture on the relevant strategies and provide specific samples, students are to digest them autonomously and come up with questions, and the teacher and students are to work together to solve these problems in classes.

Students can either finish the writing assignments given by the teacher outside of classes or finish the timed writing in classes. They are then to spend time reading and assessing the writings in pairs or groups with their peers or the teacher. They are to internalize the knowledge or develop the skills in writing in this way.

\section{The Differences Between Flipped Classroom Writing Teaching Model and the Traditional One}

The flipped classroom teaching model of writing is different from the traditional one in the following aspects:

(1) Teachers' role has changed. In a traditional writing classes, teachers dominate the class by choosing the appropriate teaching materials, deciding the important and difficult points, assigning and correcting students' writings, and controlling the whole teaching process. In a flipped classroom, both teachers and students play a significant role, but teachers are no longer dictators and controllers. They play the combined roles of mentors, counselors, collaborators, coaches, organizers, and information providers. The leading role of teachers have not been weakened, but strengthened instead (ZHANG, WANG, \& ZHANG, 2012, pp. 46-51).

(2) Students' role has changed. In a traditional writing classroom, students are to listen to the teacher's 
lectures, write the assigned compositions, wait for the teacher's feedback, and make corrections in their writings. In a flipped classroom, students are to digest the teaching content outside of the classroom by watching videos, going over the slides and reading sample writings beforehand, finish assignments either in class or after class, and interact with peers or the teacher in class for the ultimate purpose of learning. Students play the main role in class in the whole process. When the audios or videos are given to the students, they can decide when, where, how, and at what pace they are going to go over the materials and it is possible for each individual student to pause, reflect, or even restart in the course. In traditional writing classes, this is definitely impossible. Besides, in the flipped classrooms, students have to interact with their partners or the teacher to work out the problems by themselves. They are no longer the passive receiver of knowledge or skills. Rather, they have become participators, decision makers, coordinators, information gatherers, problem solvers, etc.

(3) The teaching materials have changed. In the traditional writing classroom, the teaching materials are usually confined to textbooks or PPTs, while in the flipped classroom, the teaching materials are much varied, including the textbooks, PPTs, audios, videos, or many other online resources since in the era of cloud computing and big data, there are a considerable number of teaching materials available as long as students have access to computers and the Internet. For example, the English writing course lectured by Jamaica Conner in American Liberty University is a good resource (available on the website http://open.163.com/special/opencourse/basic.html).

(4) The time allotment will be different. In the traditional writing classroom, the teacher spends most of the time lecturing in classes, whereas in the flipped writing classroom, students may spend the time writing on the spot or the teacher and students spend most of the time in class interacting with each other to solve the problems students have met with in the process of self-study before class.

(5) The feedback is given differently. In the traditional writing classroom, the students turn in the compositions they have written. Some teachers may choose to point out the errors, some teachers may choose to correct the errors, and some others may occasionally give face-to-face comments on the compositions. On students' part, some may give prompt response to the teacher's feedback and make improvements to their compositions but quite a lot of them simply turn a blind eye to the teacher's feedback or corrections. But in the flipped classroom, teachers can immediately identify students' problems in writing and students will realize the problems and correct mistakes timely. This kind of feedback may be more effective and useful.

\section{Conclusion}

Writing is one of the four integrated skills of English language acquisition. However, it is a hard nut to crack for both the teacher and students, especially non-English majors. The traditional teaching model seems not to be of much help to students.

The flipped classroom teaching model is superior to the traditional one in some ways in that it places students at the center of study both in class and outside of class and gives students more autonomy in study. Besides, it gives the teacher and students more opportunities to cooperate and interact with each other. Students are to find solutions to problems in writing themselves with the help of peers and the teacher. The application of flipped classroom teaching model is hopefully to help students to improve their proficiency in writing. But to what extent it is effective and efficient is to be decided in the future empirical studies. 


\section{References}

Flipped classroom. (n.d.). In Wikipedia. Retrieved from https://en.wikipedia.org/wiki/Flipped_classroom

HE, K. K. (2014). Look into the future of "Flipped Classroom" in China based on the nature of "Flipped Classroom". Theoretical Exploration, 35(7), 5-16.

HU, J. H. (2014). Research into the flipped classroom teaching model in college English based on MOOC. Computer-Assisted Foreign Language Education, 40-44.

JIAO, L. X. (2015). College English: A coursebook for hands-on language experiments. Beijing: Beijing University of Posts and Telecommunications Press.

JIN, L. (2016). Flipped classrooms and microlecture teaching approach. Beijing: Beijing Normal University Press.

LU, H. Y. (2014). Feasibility analysis on the application of micro-class based "Flipped Classroom" mode in college English teaching. Computer-Assisted Foreign Language Education, 35(4), 33-36.

Nunan, D. (2012). The learner-centred curriculum: A study in second language teaching. Shanghai: Shanghai Foreign Education Press.

ZHANG, J. L., WANG, Y., \& ZHANG, B. H. (2012). The research into the flipped classrom teaching mode. The Journal of Distance Education, 18(2), 46-51.

ZHONG, X., XU. X. F., \& WU, Y. Q. (2015). The application of flipped classroom teaching model in basic English Writing. English Square, 6(2), 62-64. 